〔農化 第 35 巻, 第 4 号, p. $319 \sim 322,1961$ ]

アルコール醪におけるアクロレインの生成に関する研究 (第 1 報)*

アクロレイン生成乳酸菌について

花 井四 郎 (宝酒造株式会社)

昭 和 35 年 8 月 22 日受理

アルコール醪を蒸溜する際往々分縮器からはげしい催涙性のガスの発生をみることがあるが, 著者はこの物質 を蒸溜機のいわゆる不純物処理塔から抽出される不純アルコール中に集積させて検索したところ、アクロレイン であることがわかったので先に報告した(1,2).

アクロレインの存在については Voisenet ${ }^{(3,4)}$ が 1910 年にブドー酒の刺㦸香（peppery と称した）の研究で Bacillus amaracrylus (Bacillus polymyxa) がブドー酒中のグリセリンを代謝してつくることを初めて明らかに したが，その後 Humphreys(5) は 1924 年にClostridium welchii (Cl. perfringens) が，また Warcollier ${ }^{(6,7)}$ は Cl. perfringens によってリンゴ酒やブランデー等のながアクロレインがつくられることを報告している.

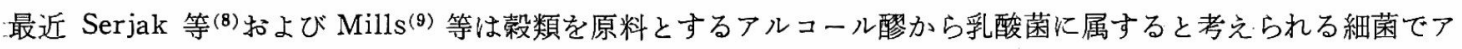

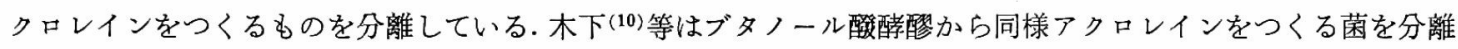
し，その一般的性質について報告している.

著者は刺㦸性ガスを発生する蒸溜樛はすべてアクロレインの検出反応である Sidney, Leonard のトリプトフ アン反応を呈すること，及びアルデヒドとして定量されるものの多いことから，これら醪からアクロレインをつ くる細菌を分離し，その菌学的諸性質を検索してへテロ酸酵乳酸菌の一種として同定したが，躌酵代謝の特異性 からその一变種とした方が適当と考㝋たので報告する.

実

験

I. 菌の分離 アクロレインの検出される醪からグリセリン・トマト汁培地（トマト汁 $400 \mathrm{cc}$, 葡萄糖 $10 \mathrm{~g}$, 酔母エキス $10 \mathrm{~g}$ ，グリセりン $20 \mathrm{~g}, \mathrm{KH}_{2} \mathrm{PO}_{4} 0.5 \mathrm{~g}, \mathrm{~K}_{2} \mathrm{HPO}_{4} 0.5 \mathrm{~g}, \mathrm{MgSO}_{4} \cdot 7 \mathrm{H}_{2} \mathrm{O} 0.2 \mathrm{~g}, \quad \mathrm{NaCl} 0.01 \mathrm{~g}$, $\mathrm{FeSO}_{4} \cdot 7 \mathrm{H}_{2} \mathrm{O} 0.01 \mathrm{~g}, \mathrm{MnSO}_{4} 0.01 \mathrm{~g}$ に蒸溜水を加えて全量を 11 とし，苛性ソーがで $\mathrm{pH}$ を 5.8 に調製した. 以下これをG.G.T. 培地と称す. 向この培地からグリセリンを除いたものはG.T. 培地とする.)を用い, 常法通 り嫌気的状態で $30^{\circ} て ゙$ 菌の分離を行った．5 日間放置した後発生したコロニーにはその周囲に Schiff の試薬を 1 滴落して直ちに大きな紅色のリングをつくるコロニーから菌を採取し，更に流動パラフィンを表面に浮べた G. ‘G.T. 培地を使用して培養し, その一部を雚溜してアクロレインの生成の有無を検出, 反応を呈するものから更 に純分離を行なった。

\title{
II. 形態学的性質
}

a. 形態大いさ： G.T. 培地で $30^{\circ}, 48$ 時間培養し たものは多く $0.4 \sim 0.7 \mu \times 1.5 \sim 4.0 \mu$ の桿状，もしく は彎曲したものが単一又は数個連鎖をなす（写真参照）

b. その他の性質： 綮汁寒天斜面の劃線培養では生 育不良, 炭酸カルシウム添加の G.T. 培地の斜面培地で 劃線培盖した場合やや生育する.炭酸カルシウム添加の 穿刺培着では上く穿刺にそって珠数状になって生育し炭 酸カルシウムを溶解する.酵母・肉エキスの液体培地(酵 母・肉エキス各ヶ $0.5 \%, \mathrm{pH} 5.8)$ では 24〜48 時間で やや混濁し始め後全体に混濁を呈する外, 液表面の器壁

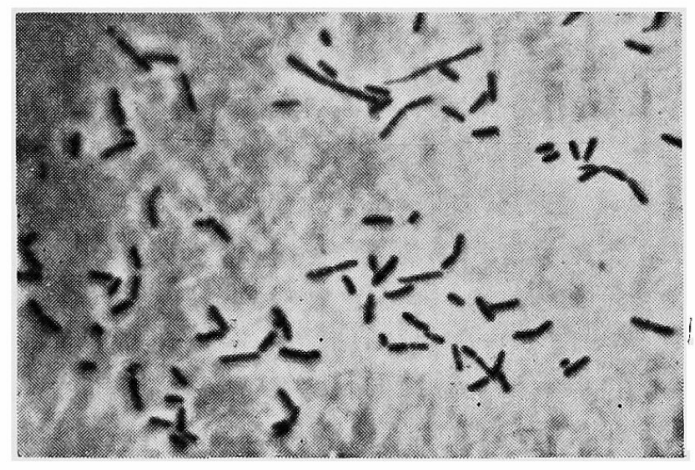

第 1 図アクロレイン生成菌の顕徽鏡写真

* Studies on the Formation of Acrolein in Alcohol Mashes. Part I. An Acrolein-Forming Lactobacillius.

By Shiro HANAI (Takara Saké-Brewing Co., Ltd.) 
部に菌の乳白出のリングをつくることがある．更にこの培地にグルコースを $1 \%$ 加光たるのでは混濁後沈渣を生 じ上部液は透明になる。平板培盖では集落は小さく周縁は entire で乳灰色のやや umbonate の形状を示す. 馬 鈴薯の平面培地には生育しない。

III. 生理学的性質 G.T. 培地，及び酵母・肉エキス培地を用いて生理学的諸性質を検討し，次のような 結果を得た。

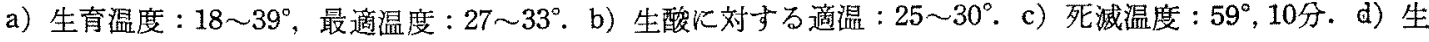
育 $\mathrm{pH}: 3.8 \sim 8.2$ の䇛囲内で生育寸るが $\mathrm{pH} 3.6$ 以下，8.4 以上では生育しない.e）がラム染色：陽性.f）運 動性：運動しない，g）胞子：つくらないｈ）ゲラチンの液化性：液化しない，）タカラーゼ：有しない，j) 硝酸塩の還元：還元しない，k) 硫化水素の生成：つくらない，1）インドールの生成：生成する，m）リトマス 牛乳の凝固：凝固しない，n）耐塩性：4\% 以上では生育しない，0) 耐アルニール性：12\% 以上では生育せず, 10\%ではやや生育が遅れるが 8\% 以下では阻書されない，p）アミラーゼ：有しない，q）ガス発生の有無：ガ スを発生する，r）色素：生成しない，s）ケト，アルデヒド類の生成：グルコール2\%, 酲母・肉エキス各々 $0.5 \%, \mathrm{pH} 5.8$ の培地に甜けるケト，アルデヒド類の生成については，フォルムアルデヒドの Legal 反応は (十), Simon 反庍は (一)、ジアセチル，アセトインについてはVan Niel 法及び Voges-Proskauer 法が共に 陰性であることからジアセチル，アセトインは生成しない。

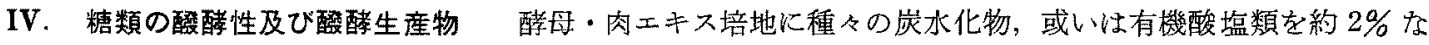

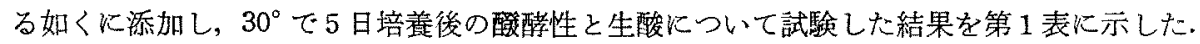

\begin{tabular}{|c|c|c|c|c|c|c|c|c|}
\hline C 秴 源 & 生育 & 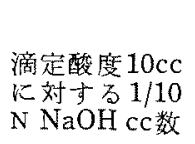 & 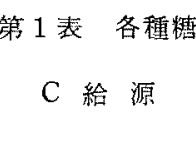 & $\begin{array}{l}\text { 頂・有 } \\
\text { 生充 }\end{array}$ & 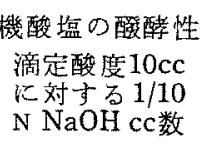 & C 釉 源 & 生充 & 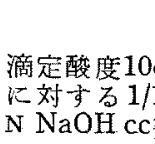 \\
\hline アラビノース & + & 4.5 & ラクトース & - & 0 & 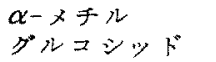 & - & 0 \\
\hline$\neq シ ロ-x$ & + & 2.1 & メリビオース & + & 3.6 & $ク^{\prime} y+y ン$ & + & 0 \\
\hline リボース & + & + & 蔗糖 & - & 0 & マンニトール & - & 0 \\
\hline ラ 厶,$-x$ & - & 0 & トレハース & - & 0 & ソルビトール & - & 0 \\
\hline グル ニース & + & 5.3 & 七ロビオース & - & 0 & インシトール & - & 0 \\
\hline$\rightarrow v,-x$ & - & 0 & シフィ, 一ス & - & 0 & ダルシトール & - & 0 \\
\hline ガラクトース & + & 1.3 & イヌリ ン & -- & 0 & $\begin{array}{l}\text { グルコン酸 } \\
\text { カルシウム }\end{array}$ & \pm & 0 \\
\hline フラクトース & + & 2.0 & デ手ストりン & - & 0 & 乳酸カルシウム & - & 0 \\
\hline ソルボース & - & 0 & 瑖 粉 & - & 0 & 䣷酸カルシウム & - & 0 \\
\hline マルトース & \pm & 0 & サリシン & - & 0 & 対 照 & - & 0 \\
\hline
\end{tabular}

酸酵生座物の試験は炭素源としてグルコース,フラクトースを用いた。即ち醰母エキス,肉エキスの各々 $0.5 \%$ を含む培地 $500 \mathrm{cc}$ Kグルニース $25 \mathrm{~g}$, 炭酸カルシウム $10 \mathrm{~g}$ を添加し, 液表面に流動パラフィンを浮かべて嫌 気的状態で $30^{\circ}$ で 7 日間培養後分析に供した。即ちその一部を硫酸酸性にして水蒸気蒸溜に附し，溜出液につい て揮発酸量を求めた，揮発酸の梌索はそのソーダ塩を濃縮しェステル化してからヒドラジンヒドレイトでヒドラ ジン㮇導体をつくりペーパークロマトグラフィーを行った(11).nーブタノールの水飽和液を展開郕とし，95\%， エタノールの $10 \%$ 塩化第二鉄液で発色させた結果, 試料の揮発酸は酢酸と同じ $R_{F}(0.45)$ を示し，酢酸の七. ドラジン誘導体の混液についても同じスポットを与えることから本菌のつくる揮発酸性酢酸であることが判明し た. 不揮発酸はこの蒸溜残液のエーテル抽出部から求め, 更にペーパークロマトグラフィー(12)を行うため, 濃縮 し少量の硫酸アンモニアを加えて不揮発酸のアンモニア塩とした. $95 \%$ エタノール，アンモニア，水の比率が 80:5:15 からなる展開剤を用い上具法で展開, のらブロムフェノールブリニー $50 \mathrm{mg}$, クェン酸 $200 \mathrm{mg}$, 水 $100 \mathrm{ml}$ からなる発色剂で呈色させた結果, 本菌のつくる不揮発酸恬乳酸の $R_{F}(0.54)$ と一致する唯一つのスポ ットを与えたので, 更にこのエーテル抽出部の乳酸を $Z n$ 塩として晶出させ, 水で再結して分析に供した. この $\mathrm{Zn}$ 塩の結晶水は $18.14 \%$ ，灼熱残椬の $\mathrm{ZnO}$ は $27.54 \% ，[\alpha]_{\mathrm{D}}^{25} \pm 0$ でこれはDL-型乳酸の各々とよく一致する ことから本菌のつくる乳酸は DL 型であることがわかった.フラタトースの場合もグルコースと同し方法によっ てつくった培盖液に接種し，30゚で20日間培養のち，前記と全く同じ方法て分析した結果，ダルコースの場合 ル和けるとれと全く同じ結果を与光た、マンニトールの抽出と定量はその培養液中に残存するフラクトースをパ 
第 2 表 アクロレイン生成菌の酸醉生座物

\begin{tabular}{|c|c|c|c|c|c|c|c|c|c|c|c|c|}
\hline \multirow[b]{2}{*}{$\mathrm{C}$ 給 源 } & \multirow[b]{2}{*}{$\begin{array}{l}\text { 培盖 } \\
\text { 日数 }\end{array}$} & \multicolumn{3}{|c|}{ 䊈 } & \multirow{2}{*}{$\frac{\text { 乳 }}{\text { 生成量 }}$} & 酸 & 酢 & 酸 & \multicolumn{2}{|c|}{ フルコール } & \multicolumn{2}{|c|}{ マンニトール } \\
\hline & & $\begin{array}{l}\text { 接種 } \\
\text { 前 } \\
(\mathrm{g})\end{array}$ & $\begin{array}{l}\text { 培目 } \\
\text { 後 } \\
(\mathrm{g})\end{array}$ & $\begin{array}{l}\text { 消費 } \\
\text { 率 } \\
(\%)\end{array}$ & & $\begin{array}{c}\text { 消費糡 } \\
\text { 対す } \\
\text { る割合 } \\
(\%)\end{array}$ & $\begin{array}{c}\text { 生成量 } \\
\text { (g) }\end{array}$ & $\begin{array}{c}\text { 消費糖 } \\
\text { 対与 } \\
\text { る敖合 } \\
(\%)\end{array}$ & $\begin{array}{c}\text { 生成量 } \\
\text { (g) }\end{array}$ & 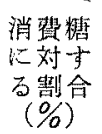 & $\begin{array}{c}\text { 生成量 } \\
\text { (g) }\end{array}$ & 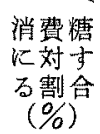 \\
\hline フラクトーメ & 25 & 5.12 & 0.59 & 89 & 1. 29 & 29 & 0.34 & 7.5 & 0.84 & 18.6 & 0.79 & 18.2 \\
\hline グルコース & 7 & 5.24 & 0.07 & 99 & 1.77 & 34 & 0.15 & 2.8 & 1.07 & 20.7 & & \\
\hline
\end{tabular}

ン酵母で酸酵消失させたのら，硫酸酸性でエーテル抽出を行ない，つぎに残液を中和してから約 $1 / 3$ 量まで減仕 濃縮し，これにアルコール濃度が 50\% 位になる程度にェタノールを加えて沈搌を濾去し，その濾液を更に隇圧 濃樎してシラップ状となし，このシラップの $80 \%$ エタノール可溶部からエタノールを駆出して得たシラップ状 の残夜に無水アルコールを加光た。ここに生じた沈澱を除いて，その液を水室内に放置し晶出した結晶を分取し たが微量のためペーパークロマトグラフィー(13)を行ってマンニトールを確認した. 即ら試料の水溶液を濾紙上に

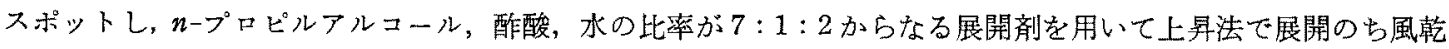

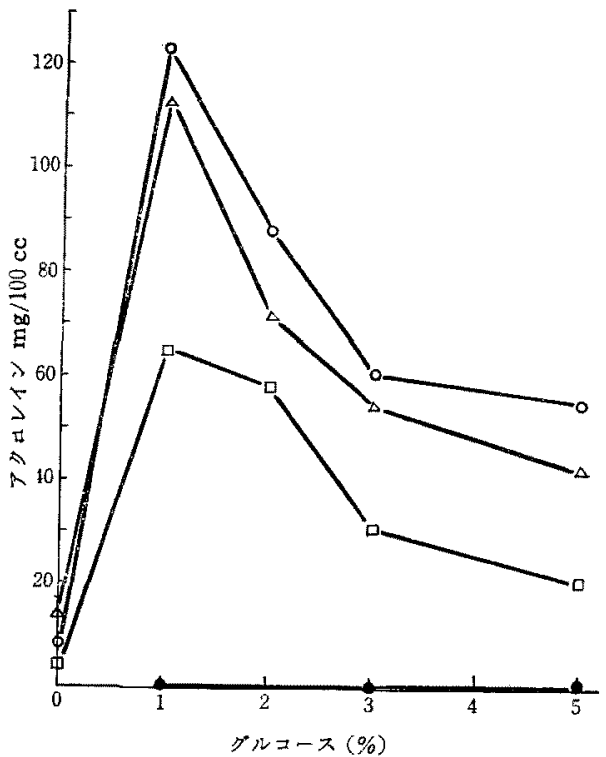

第 2 図 グリセリン，诪漂度の相異によるアクは レインの生成 (Lactobacillus brevis との比较)

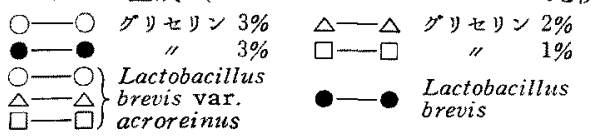

第 3 表 アクロレイン生成菌の各種物翼に対する作用 検出反応 アクロレイン アルデヒド ジタトン検出

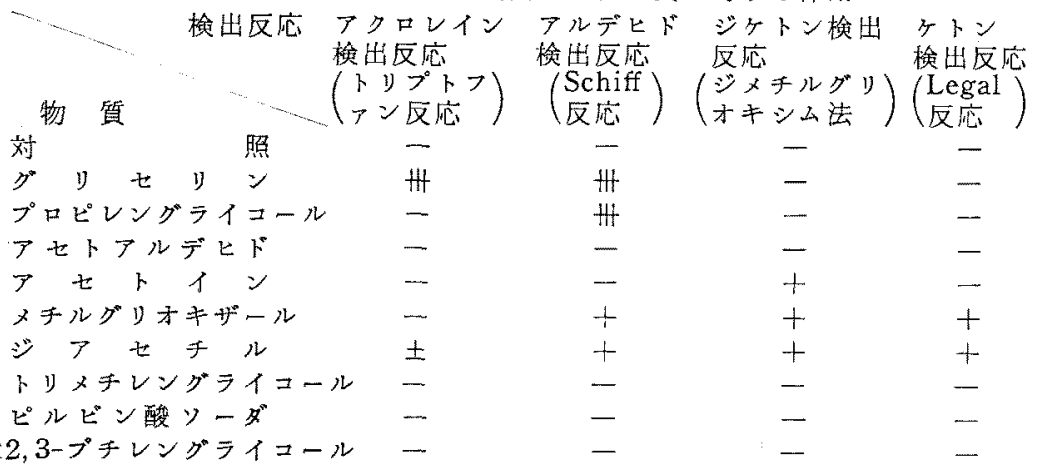

し，この濾紙を $0.5 \%$ $5 \%$ アジン・タノール液 $(0.5 \mathrm{~g}$ アニシジンを $3 \mathrm{ml}$ の $85 \%$ 殊酸に溶解のち $80 \%$ × タノール $100 \mathrm{ml}$ を加光る）に浸積する。次いで余分 の液老除いてから $105^{\circ}$ て約 10 分閒加熱すると粕アル コールは焦荼色になった濾紙上に白色のスポットとし て残る。本試料はマンニトールと同じ $R_{F}(0.20)$ を 与え, 更にマンニトールとの混液も唯一のスポットを 与えることから本物筫はマンニトールと確認した。定 量はパン酸母で残糖を除いた日のについて Smit 法て 行なった.グルコース，フラクトースの酹酵代謝生産 物の量比悌 2 表に示した. 即ち本菌は前述の菌学的

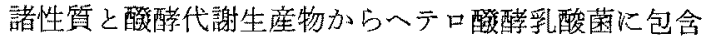
される青のと考视られる。

\section{V. グリセリン及びその他の物質に対する作用} グリセリンからアクロレインを生成する反応は本菌の 脱水作用に基くものであるが、この場合グリとリンと グルコースの濃度を変えた培養液を用いて $30^{\circ}$ で 5 日 間培坦したのらのアクロレインの生成量について試路 した結果を第 2 図に示した.アクロレインの生成量保 どのグリセりン濃度の場合でもグルコースが $1 \%$ の時 が最も多く糖濃度が高くなるに徉って減少した。比慗 のため Lactobacillus brevis に ついてす同様に試験したが，ア クロレインはつくられなかった。 次いでダリセりンが代謝され てアクトレインをつくったと同 じよ5に他の物質でもこの脱水 反応孛引けてアクロレイン，又 は類似物貿を生成する場合が女 るか模索したところ，第 3 表に 示さ礼るよらにアクロレインは グリ七りンからの欢つくられ， 


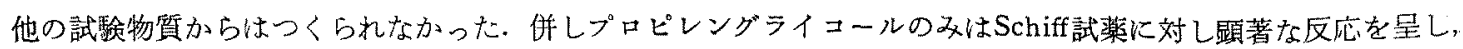
明らかにアルデヒド系物質の存在を示した，徒ってこのものを検索するため蒸溜液についてベンゾール・スルフ オン・ヒドロキシラミン酸でアルデヒドのヒドロキサム酸をつくり,イソ・アミルアルュール, 水酶酸, 蒸溜水 が $5: 1: 1$ の比率からなる展開郕を用いてペーパークロマトグラフィー(14)を行った. 展開後塩化第二銠のブタ ノール飽和溶液で発色させたところ，プロピルアルデヒドのそれと一致する $R_{F}(0.64)$ を示したので，次いで 2,4-ジニトロフェニールヒドラジンをつくってェタノールて再結, 融点を測った. その結果 $154^{\circ}$ の融点を示し プロピルアルデヒドのそれと一致すると共に，混融するも融点降下はみられなかったので本菌はプロピレングラ イコールに作用してプロピルアルデとドを生成することが判明した，対照として Lactobacillus brevisについて も同様の試験を行なったが，プロピレングライコールからはプロピルアルデとドは生成されなかった。

\section{考察}

著者がアルコール醪から分離したグりセりンを代謝してアクロレインを生成する細菌は前述の菌学的諸性質と 醴酵代謝生成物からみて，明らかにへテロ酶醉乳酸菌に包含されるものであり，Bergey's Manual of Determi一 native Bacteriology (6 th ed.) の分類表によれば Genus Lactobacillus II 群に，北原の分類表に照し合せる時

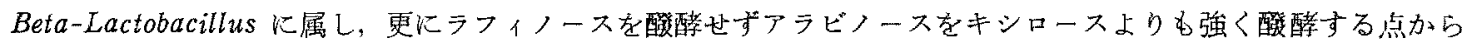
Lactobacillus brevis に同定されるべきのと考光られる. 更に既知のアクロレイン生成菌として報告されてい るものと比較するに, Voisenet の Bacillus amarycrylus や Humphreys $の$ Clostridium welchii 或いは Warcollier の Cl. perfringens 等は明らか炕異なる種属のものであり，木下，Mills，Serjak 等の分離菌に関する報 告には菌学的諸性質についての詳細な記載がないが，木下の分離菌が乳酸酸醭菌としても糖類からがスの発生が みられない点著しい違いがあり，又 Millsの分離菌怯硝酸塩を還元することから異なる菌種と考点られる. Serjak の分離菌は L. plantarum, L. brevis, L. buchneri, L. pastorianus とは異なりフラクトース，キシロース，

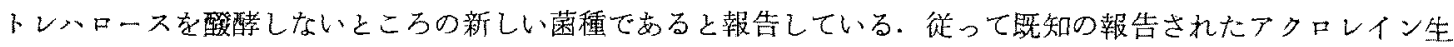
成菌のらちには著者の分離したアクロレイン生成菌と一致するものは見出し得なかった。

ひるが党って本菌が分類学的には Lactobacillus brevis 炕同定されるに拘らずグりセりンからアタロレイン を，プロビレングライコールからはプロピルアルデヒドを生成する脱水作用のあることよりその一変種と認め， Lactobacillus brevis var. acroreinus とすることを提唱する.

\section{要 的}

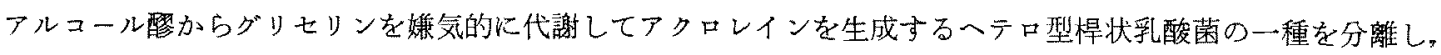

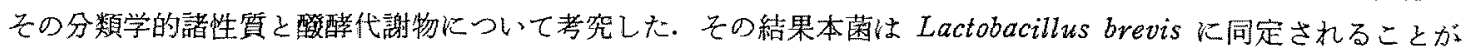
わかったが，グリセりンからアクロレインを，又プロピレングライコールからプロピルアルデヒドを生成する特 異性のあることから Lactobacillus brevis の一変種と認めることが適当と考光, 更に既知の報告されたアクロレ イン生成茵と一致するものを見出し得なかったので，本菌を Lactobacillus brevis var. acroreinus とすること を提唱する。

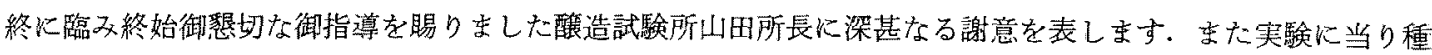
々御教授を頂きました北海道大学佐々木教授，応微研第一研究室福井助教授に厚く御礼申上げます。また実験と 発表に便宜を与克られました当社田中社長，小穴部長及び前田工場長に感謝申上げます。

（1）花井四郎，正井成之，佐多木定，山田正一： 醇協，51，920 (1956).

（2）花井四郎：醇協，54，114（1959）.

(3) M. E. Viosenet : Compt. rend. (Acad. Sci.), 153, 363 (1911).

(4) M. E. Viosenet : ibid., 156, 1181(1913).

(5) F. B. Humphreys: J. Infections Dis., 35, 282 (1924).

(6) G.Warcollier, A, Le Moal : Compt.rend., 194, 1394 (1932).

(7) G. Warcollier, A. Le Moal, J. Taverneir : ibid., 198, 1546 (1934).

(8) W.C. Serjak, W. H. Day, g. M. van Lanen, C.S. Boruff: App. Microbiol., 2, 14(1953).

(9) Doris E. Mills, W. D. Baugh, H. A. Conner : ibid., 2, 9 (1953).

（10）木下祝郎，奥村拓二：酸協，16, 449(1958).

(11) 井上吉之： 本誌，24，291 (1951).

(12) E. P. Kenedy, H. A. Bapker: Anal. Chem., 23, 1033 (1951).

(13) J. Cerbulis : ibid., 27, 1400 (1955).

(14) 宇野兵治郎, 小山 炳：酸工, 29, 219(1951). 